\title{
Three types of suffixes in French
}

\section{Discarding the learned / non-learned distinction ${ }^{\star}$}

\author{
Jan Don, Petra Sleeman and Thom Westveer \\ University of Amsterdam
}

Traditionally a two-way distinction is made in French between learned and non-learned suffixes, based on etymology. However, this distinction does not account for all suffixes. Furthermore, suffixes are traditionally considered as categorial heads, but some suffixes derive words of multiple categories. This paper proposes an alternative analysis of French suffixes, distinguishing three instead of two types, using a theory by Creemers et al. (2015) proposed for Dutch. In their analysis in the framework of Distributed Morphology, Creemers et al. distinguish three instead of two types of suffixes, proposing an alternative to Lowenstamm (2010). Starting from their proposal, we show that it is possible to distinguish three types of suffixes in French as well, accounting for the categorial flexibility of some suffixes, without resorting to the vague distinction between learned and non-learned.

Keywords: morphological derivation, French, categorial flexibility, learned vs. non-learned, Distributed Morphology

\section{Introduction}

Traditionally, in French a distinction is made between two types of suffixes, learned and non-learned. This distinction is mainly made on the basis of whether a suffix triggers a rule of Learned Backing (hereafter: LB) or not (Dell \& Selkirk 1978). This is a vocalic change, involving the front vowels $/ \varepsilon /$ and $/ \mathrm{E} /$, that change into the back vowels $/ \mathrm{a} /$ and $/ \mathrm{J} /$ respectively. Only learned suffixes (suffixes savants), which were borrowed from Latin in the mediaeval period or later, trigger this rule. Examples are given in (1) and (2):

\footnotetext{
* We would like to thank two anonymous reviewers for valuable comments and suggestions.
} 
(1) Learned suffixes

$\begin{array}{lll}-i t e ́ & \text { céc-ité } & \text { 'blindness' } \\ -a l & \text { nomin-al } & \text { 'nominal' }\end{array}$

(2) Non-learned suffixes

$\begin{array}{lll}\text {-age bavard-age 'chatter' } & \\ \text {-té beau-té } & \text { 'beauty' }\end{array}$

Learned Backing is illustrated in (3).

(3) non-learned learned
a. mer a-merr-ir mar-in
'sea' 'to land at sea' 'sailor'
b. fleur fleur-ir flor-al
'flower' 'to flower' 'flowerish'

As can be expected, the learned suffixes can also be subject to this vocalic change themselves when followed by another learned suffix (4):
(4)
a. danger-eux
'dangerous'
danger-ós-ité ${ }^{L}$
b. joy-êux
'dangerousness'
'joyful'
joy-eus-eté ${ }^{N L}$
'joyfulness'

Unfortunately, the distinction between learned and non-learned suffixes is not always that clear-cut. In fact, only when there is LB can one verify whether a suffix is learned or not. In other cases, the classification of a suffix is based on the date of introduction in the language. Of course, such criteria are not available to the language-learning child and should therefore be avoided. Therefore, the main goal of the present paper is to give the distinction between learned and non-learned suffixes in French a more firm empirical and theoretical foundation.

A second somewhat problematic issue for traditional approaches towards French morphology is the existence of suffixes that are categorially flexible. That is, some suffixes derive words of which some are adjectival whereas others are nouns, as is shown in (5):

(5) a. nominal: une boit-euse $e^{N}$

$$
\text { 'a cripple (woman)' }
$$

b. adjectival: une fête joy-euse $e^{A}$

'a joyful party'

c. both: un cosmopol-ite ${ }^{N}$, un homme très cosmopol-ite ${ }^{A}$ 'a cosmopolitan', 'a very cosmopolitan man' 
The same suffix can derive a noun, as in (5a), and an adjective, as in (5b). The suffix in (5c) forms a special case. Based on the same root cosmopol-it can derive both a noun and an adjective.

Zwanenburg (1986) considers the suffixes in (5) as being either nominal or adjectival suffixes. He argues that these should be registered as such in the lexicon. The adjectival use of a nominal suffix or the nominal use of an adjectival suffix is (i) allowed by syntax, or (ii) should be mentioned in the lexicon for each noun separately. We think this proposal is unnecessarily complicated and can be avoided if one allows suffixes to be categorially flexible.

In order to deal with these two problematic issues, we propose a new analysis, based on a theory by Creemers, Don \& Fenger (2015) (hereafter CDF) for Dutch. They distinguish three types of suffixes, instead of two, as traditionally assumed for Dutch, and argue that some suffixes should be seen as roots, whereas others are categorial heads, thus accounting for both stress-sensitivity and categorial flexibility of some suffixes. We show that this theory also holds for French. This analysis allows us to distinguish different types of suffixes without having to rely on the vague distinction between learned and non-learned elements. Secondly, the analysis also explains why some suffixes are categorially flexible, whilst others are not. The analysis is couched within the framework of Distributed Morphology (hereafter DM) (Halle \& Marantz 1993; Harley \& Noyer 1999; Marantz 2007). It would extend the limits of this paper to defend this choice (but see e.g. Marantz 1997 for arguments against a lexicalist approach). However, given this choice an alternative has to be found for the observations that received an explanation in terms of levelordering in lexical approaches to morphology (see e.g. Kiparsky 1982).

Building on a proposal by Lowenstamm (2010), who argues that all affixes are roots, we propose that some affixes are roots, whereas others are categorial heads. In the next section, we will introduce the theory proposed by CDF for Dutch that will be used as a basis for our analysis. In Section 3 we will present our analysis of the French suffixes according to this proposal. In Section 4 we will turn to problematic cases that at first sight seem to contradict the theory. A brief conclusion will be given in the final section.

\section{Three types of affixes}

We propose an analysis for the French data along the lines of CDF's analysis for Dutch. We first briefly introduce CDF's proposal before we turn to our analysis of the French data.

In Dutch traditionally a distinction is made between two types of affixes, based on their behavior w.r.t. stress-rules (e.g. Trommelen \& Zonneveld 1989). 
Dutch hosts stress-sensitive suffixes influencing the stress-pattern of the base and stress-neutral suffixes that do not.

In DM, a separation is made between a (morpho-) syntactic level of representation and the morpho-phonological level of representation (cf. Beard 1995). This latter level can be seen as 'realizing' or 'spelling out' the morpho-syntactic level. Affixes are seen as so-called Vocabulary Items (hereafter: VI) realizing categorial heads (Marantz 1997; Marvin 2003). So, English -ity is a VI realizing a nominal head. Since the VI's themselves do not contain any grammatical information, but only realize this, it is far from trivial to transpose the traditional distinction between stress-sensitive and stress-neutral affixes to the theory of DM. ${ }^{1}$

Secondly, being categorial heads, the affixes are expected to derive just a single category of words, but CDF (following De Belder 2011) show that also in Dutch there is a group of flexible affixes that in the sense that they derive words belonging to different categories - similar to what we have seen in (5) for French.

In order to try to account for the distinction between stress-sensitive and stress-neutral suffixes within the framework of DM, Lowenstamm (2010) argues, contrary to the traditional view in DM, that suffixes are not categorial heads, but bound roots. As bound roots, these suffixes do not have a category, hence their categorial flexibility. For Lowenstamm, the classical distinction between stressneutral and stress-sensitive falls out from a distinction in the type of element with which the morpheme merges. Roughly, stress-sensitive affixes only merge with roots, whereas stress-neutral affixes only merge with already categorized structures. Assuming that categorial heads are phase-boundaries, Lowenstamm is able to derive the distinction between stress-neutrality and stress-sensitivity from the different structural position that these elements occupy.

CDF criticize Lowenstamm's proposal. They point out that there is a class of affixes that does not display the categorial flexibility one would expect if all affixes were indeed roots. Moreover, they observe a correlation between categorial flexibility and stress-sensitivity on the one hand, and lack of flexibility and stressneutrality on the other. More specifically CDF's alternative proposal distinguishes three types of affixes: root affixes that are flexible, attach to roots, and are stresssensitive; head-affixes that are categorially rigid, only attach to categorized words, and are stress-neutral; and thirdly a type of affix that behaves as head-affixes but does influence the stress-pattern. CDF calls these latter affixes 'first heads' for reasons that will become immediately clear.

We summarize the types of affixes and their properties in table (6):

1. See Marvin (2003) for an attempt in which Halle \& Vergnaud's (1987) distinction between cyclic and non-cyclic affixes is incorporated. Lowenstamm (2010) criticizes this attempt and offers an alternative approach. 
(6)

\begin{tabular}{llll}
\hline & Attach to roots & Stress-sensitive & Categorially flexible \\
\hline Root-affixes & + & + & + \\
First heads & + & + & - \\
Head-affixes & - & - & - \\
\hline
\end{tabular}

All affixes that attach to roots are also stress-sensitive. Furthermore, categorial flexibility is a property exclusive to root-affixes. CDF claim that the correlating properties in (6) are not coincidental, but follow from the position of the morphemes realized by the affixes in the syntactic structure. The place of the suffixes in the syntactic structure is shown in (7):

(7)

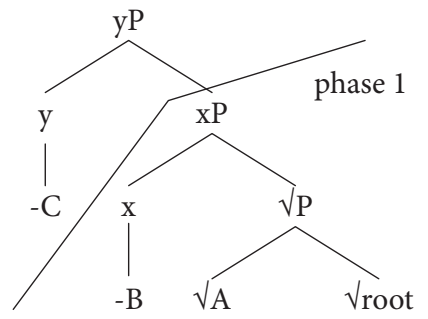

$$
\begin{aligned}
& A=\text { root-affixes } \\
& B=\text { first heads } \\
& C=\text { head-affixes }
\end{aligned}
$$

As can be seen, both root-affixes (A) and 'first heads' (B) appear in the first phase. This directly follows from the way phases are defined by Embick (2010). A phase is determined by a categorial head which has a cyclic head in its complement. Since $\mathrm{B}$ in (7) does not have a cyclic head in its complement, $\mathrm{B}$ is spelled out in the same phase as the root-affixes; it is a first head. $C$ is in a different phase since it is a head with a cyclic head (B) in its complement. A phase is phonologically (and semantically) interpreted. Therefore, only affixes in the first phase will be able to influence the stress-pattern of the base. Later attaching affixes cannot because at this stage, the phonological form of the inner phase is already fixed.

CDF test their proposal for Dutch. It turns out that it is indeed possible to empirically separate in Dutch the three types of suffixes mentioned above. Examples are given in (8) (the underlined parts mark stressed syllables):

(8) a. Root-affix:

$\begin{array}{ll}\text {-ief explos } & \text { explos-ief } \\ \text { 'root' } & \text { 'explosive' }\end{array}$

b. First head:

$\begin{array}{lll}\text {-iteit } & \text { flexibel } & \text { flexibil-iteit } \\ \text { 'flexible' } & \text { 'flexibility' }\end{array}$

c. Head-affix:

$\begin{array}{lll}\text {-ing } & \text { verhuis } & \text { verhuiz-ing } \\ \text { affix-house } & \text { affix-house-ing } \\ \text { 'to move' } & \text { 'moving' }\end{array}$


As can be seen, root-affixes (8a), as well as first heads (8b) influence the stresspattern, whereas this is not the case for head-affixes (8c). Second, the word in (8a), containing a root-affix, can be used both as a noun and as an adjective, thus being categorially flexible, whereas the others $(8 b-c)$ cannot. In the next section we will turn to our analysis of the French suffixes, using the criteria introduced by CDF.

\section{An alternative analysis of French suffixes}

As has been shown in the introduction, the traditional distinction between two types of suffixes in French is not always clear-cut. In some cases criteria to determine whether a suffix is learned or non-learned do not converge. Secondly, some suffixes derive words of multiple categories for which no natural solution seems to exist within lexicalist approaches. In this section, we propose a different approach towards the classification of French suffix types that captures these problematic properties. Our distinction is based on the proposal by CDF for Dutch (see Section 2).

The most common French suffixes have been analyzed according to the properties proposed by CDF. We used the list of suffixes of the Petit Robert dictionary of French (2012) as an empirical basis for our analysis. This list contains 113 suffixes. Of this list, 37 suffixes have been excluded, because they were either extremely unproductive or had a highly specialized connotation used only in jargon (e.g. -ose in fructose). On the other hand, one supplementary suffix not in the list (-uble) has been added. This resulted in a corpus of 77 suffixes. In order to get information about their distribution, their behavior w.r.t. LB and their categorial and ordering properties, we used the dictionaries Petit Robert électronique (hereafter PRE) and the Trésor de la langue française informatisé (Dendien 2015), as well as Dell \& Selkirk (1978).

The analysis according to the criteria mentioned above primarily divides the suffixes under consideration into two groups. For the moment, we will call them type I and type II suffixes. Their properties are displayed in table (9):

\begin{tabular}{|c|c|c|c|c|}
\hline & Attach to roots & Trigger LB & $\begin{array}{l}\text { Categorially } \\
\text { flexible }\end{array}$ & $\begin{array}{l}\text { Ordering } \\
((<'=\text { 'linearly precedes') }\end{array}$ \\
\hline Type I & + & + & + & $\begin{array}{l}\mathrm{I}<\mathrm{II}, \mathrm{I}<\mathrm{I} \\
{ }^{*} \mathrm{II}<\mathrm{I}\end{array}$ \\
\hline Type II & - & - & - & $\begin{array}{l}\mathrm{I}<\mathrm{II}, \mathrm{II}<\mathrm{II} \\
\star \mathrm{II}<\mathrm{I}\end{array}$ \\
\hline
\end{tabular}


As can be seen in (9), the suffixes of the first type attach to roots, trigger LB, are categorially flexible, and can be followed by suffixes of type I or II, whereas they cannot follow a type II suffix. Type II suffixes cannot attach to roots, do not trigger LB, and are categorially fixed. They can be followed by type II suffixes, but not by type I. We will now illustrate these two suffix types with some examples.

Table (10) displays some typical examples ${ }^{2}$ of the aforementioned type II suffixes of French: ${ }^{3}$

\begin{tabular}{|c|c|c|c|c|}
\hline Suffix & Derives & Attaches to & Examples & Triggers LB \\
\hline -age & $\mathrm{N}$ & $\mathrm{N}$ & gazonnage, & no (e.g. fleurage) \\
\hline -aison & $\mathrm{N}$ & $\begin{array}{l}\mathrm{V} \\
\mathrm{N}\end{array}$ & $\begin{array}{l}\text { accostage } \\
\text { siglaison, } \\
\text { comparaison }\end{array}$ & no (e.g. fleuraison) \\
\hline -esque & A & $\mathrm{N}$ & moliéresque, ubuesque & no \\
\hline -eur/-euse & $\mathrm{N}$ & $\mathrm{V}$ & voyeur, chanteur, chanteuse & no \\
\hline -té & $\mathrm{N}$ & A & étrangeté, beauté & no (e.g. joyeuseté) \\
\hline
\end{tabular}

As can be concluded from table (10), type II suffixes do not attach to roots, but only to words already having a category. Secondly, they only derive words of a single category, so they are not categorially flexible. Finally, they do not trigger LB. Our corpus contains in total 37 of these type II suffixes.

In table (11) some typical examples of French type I suffixes are given. The corpus contains 26 of these suffixes:

\begin{tabular}{lllll}
\hline Suffix & Derives & Attaches to & Examples & LB? \\
\hline -ain/-an & $\mathrm{N}$ & bound roots & $\begin{array}{l}\text { humain, } \\
\text { chapelain, } \\
\text { couvain, } \\
\text { humain, }\end{array}$ & $\begin{array}{l}\text { Affected by LB: } \\
\text { humain }>\text { humanité } \\
\text { africain }>\text { africanisme }\end{array}$ \\
& & $\mathrm{N}$ & \\
& $\mathrm{V}$ & bound roots & $\begin{array}{l}\text { mondain, } \\
\text { hautain, }\end{array}$ & \\
& & $\mathrm{N}$ & $\mathrm{A}$ & Affected by LB: \\
-al/-el & $\mathrm{A}$ & bound roots & $\begin{array}{l}\text { nominal, } \\
\text { collégial, } \\
\text { continuel, }\end{array}$ & $\begin{array}{l}\text { maternel }>\text { maternaliser } \\
\text { actuel }>\text { actualité } \\
\text { culturel }>\text { culturalisme } \\
\end{array}$ \\
& & $\mathrm{N}$ & $\mathrm{A}$ & Triggers LB: \\
& $\mathrm{N}$ & bound roots & & chour $>$ choral
\end{tabular}

2. The complete lists for all suffix-types are included in the appendix.

3. Translations of the derived words are not relevant to our analysis and therefore not included. 


\begin{tabular}{|c|c|c|c|c|}
\hline $\begin{array}{l}-(t) \text { eur/ } \\
-(t) \text { rice }\end{array}$ & $\mathrm{N}$ & $\begin{array}{l}\text { bound roots } \\
\mathrm{N}\end{array}$ & $\begin{array}{l}\text { acteur, amateur, } \\
\text { ambassadeur, }\end{array}$ & $\begin{array}{l}\text { Affected by LB: } \\
\text { professeur > professorat }\end{array}$ \\
\hline $\begin{array}{l}-e u r \\
(-o r)\end{array}$ & A & $\begin{array}{l}\mathrm{V} \\
\text { bound roots } \\
\mathrm{V}\end{array}$ & $\begin{array}{l}\text { charmeur, } \\
\text { attracteur, } \\
\text { abaisseur }\end{array}$ & \\
\hline $\begin{array}{l}-e u x / \\
\text {-euse } \\
(-o s)\end{array}$ & $\mathrm{N}$ & $\begin{array}{l}\text { bound roots } \\
\mathrm{N} \\
\mathrm{V} \\
\text { bound roots } \\
\mathrm{N} \\
\mathrm{V}\end{array}$ & $\begin{array}{l}\text { taiseux, } \\
\text { siffleux, } \\
\text { boiteuse, } \\
\text { nitreux, } \\
\text { joyeux, } \\
\text { boiteux }\end{array}$ & $\begin{array}{l}\text { Affected by LB: } \\
\text { dangereux > dangerosité } \\
\text { nitreux }>\text { nitrosation } \\
\text { adipeux > adiposité } \\
\text { Triggers LB: } \\
\text { vapeur > vaporeux }\end{array}$ \\
\hline -iste & $\mathrm{N}$ & $\begin{array}{l}\text { bound roots } \\
\text { N } \\
\text { A } \\
\text { V } \\
\text { bound roots } \\
\text { N } \\
\text { A } \\
\text { V }\end{array}$ & $\begin{array}{l}\text { graphiste, } \\
\text { latiniste, } \\
\text { spécialiste, } \\
\text { arriviste, } \\
\text { alpiniste, } \\
\text { latiniste, } \\
\text { spécialiste, } \\
\text { arriviste }\end{array}$ & $\begin{array}{l}\text { Triggers LB: } \\
\text { criminel > criminaliste } \\
\text { matériel > matérialiste }\end{array}$ \\
\hline
\end{tabular}

As can be observed in (11), the French type I suffixes can attach to bound roots, as well as to categorized words. Secondly, they are categorially flexible in that they can derive both nouns and adjectives. Finally, as the final column in (11) shows, type I suffixes trigger LB or are affected by it. The fact that not all type I suffixes can be affected by LB has a clear phonological explanation: the absence of a front vowel that can undergo LB.

So far, two distinct types of suffixes for French have been introduced. However, there still remain some suffixes (12) that do not seem to fit either of these two types. As CDF predict, there is a third intermediate suffix-type, the first head, which contains these remaining suffixes. Some examples of these remaining suffixes are displayed in table (12):

\begin{tabular}{lllll}
\hline Suffix & Derives & Attaches to & Examples & Triggers LB \\
\hline -ation & $\mathrm{N}$ & bound roots & $\begin{array}{l}\text { corporation, } \\
\text { frustration }\end{array}$ & nitreux $>$ nitrosation \\
& & $\mathrm{V}$ & mécaniser, & annuel $>$ annualiser \\
-is(er) & $\mathrm{V}$ & bound roots & valgaire $>$ vulgariser \\
& & $\mathrm{N}$ & caraméliser, & maternel $>$ maternaliser \\
& & $\mathrm{A}$ & moderniser & africain $>$ africanisme \\
-isme & $\mathrm{N}$ & bound roots & dynamisme, & terreur $>$ terrorisme \\
& & $\mathrm{N}$ & marxisme, & \\
& & $\mathrm{A}$ & modernisme, & \\
& & $\mathrm{V}$ & arrivisme &
\end{tabular}




\begin{tabular}{cclll}
-ité & $\mathrm{N}$ & $\begin{array}{l}\text { bound roots } \\
\mathrm{A}\end{array}$ & $\begin{array}{l}\text { cécité, vérité, } \\
\text { modalité }\end{array}$ & $\begin{array}{l}\text { actuel }>\text { actualité } \\
\text { dangereux }>\text { dangerosité }\end{array}$ \\
-itude & $\mathrm{N}$ & $\begin{array}{l}\text { bound roots } \\
\mathrm{N}\end{array}$ & $\begin{array}{l}\text { altitude, latitude, } \\
\text { négritude, } \\
\text { exactitude }\end{array}$ & seul $>$ solitude \\
& $\mathrm{A}$ & extude & \\
\hline
\end{tabular}

Table (12) shows that these intermediate-type suffixes attach to roots and to words having a category, just like the type I suffixes presented above. They trigger LB as well. However, they are not categorially flexible, but only derive words of a single category, like the type II suffixes. They do not undergo LB since there is never a following triggering suffix. Thus, they display properties of both type I (attach to roots, trigger LB) as well as of type II suffixes (categorial inflexibility) and form an intermediate type.

In order to compare the three types of suffixes found in our corpus, their properties w.r.t. the criteria used to distinguish them are summarized in table (13):

\begin{tabular}{|c|c|c|c|c|}
\hline & Attach to roots & Trigger LB & $\begin{array}{l}\text { Categorially } \\
\text { flexible }\end{array}$ & Ordering \\
\hline $\begin{array}{l}\text { Type I } \\
\text { Root-suffixes }\end{array}$ & + & $\begin{array}{l}+ \\
(+ \text { affected })\end{array}$ & + & $\begin{array}{l}\mathrm{I}<\mathrm{II}, \mathrm{I}<\mathrm{I} \\
{ }^{\star} \mathrm{II}<\mathrm{I}\end{array}$ \\
\hline $\begin{array}{l}\text { Type Ia } \\
\text { First heads }\end{array}$ & + & + & - & $\begin{array}{l}\mathrm{I}<\mathrm{Ia}<\mathrm{II} \\
{ }^{\star} \mathrm{II}<\mathrm{Ia} \\
{ }^{\star} \mathrm{Ia}<\mathrm{I} \\
{ }^{\star} \mathrm{Ia}<\mathrm{Ia}\end{array}$ \\
\hline $\begin{array}{l}\text { Type II } \\
\text { Head-suffixes }\end{array}$ & - & - & - & $\begin{array}{l}\mathrm{I}<\mathrm{II}, \mathrm{II}<\mathrm{II} \\
{ }^{\star} \mathrm{II}<\mathrm{I}\end{array}$ \\
\hline
\end{tabular}

As can be concluded from (13), the French suffixes in our corpus can be divided into three different types that are identical to the three types of suffixes CDF distinguish for Dutch. The root-suffixes (type I) can attach to roots, trigger and are affected by LB and are categorially flexible. The first heads (type Ia) form an intermediate type. They can attach to roots and trigger LB, just as the root-suffixes, but they are not categorially flexible and are not affected by LB. In this respect, they resemble head-suffixes (type II), which are not categorially flexible either. Yet, head suffixes, in contrast to first heads, cannot attach to roots and do not trigger LB.

As suggested by the empirical data, the three types of suffixes display a hierarchy w.r.t their ordering in combinations of multiple suffixes. Root-suffixes always appear inside first heads, which in turn always appear inside head-suffixes, as shown in (14): ${ }^{4}$

4. There seem to be some apparent counterexamples to this ordering hierarchy. We will address them in Section 4. 


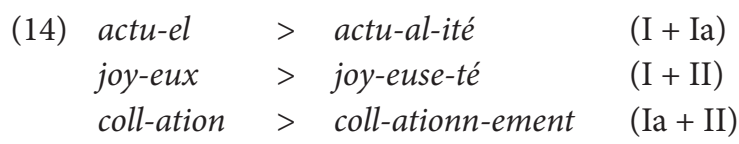

Furthermore, as has been mentioned, it is possible to combine two root-suffixes and two head-suffixes, but not two first heads. This follows directly from the definition of a first head: it is only the first head above the root phrase that behaves as such; all later heads have a categorial head in their complement and therefore induce new phases.

\section{Apparent counterexamples in French}

As has been shown in the previous section, it seems possible to distinguish three types of suffixes in French based on categorial flexibility, attachment to roots, LB and ordering, replacing the vague distinction between learned and non-learned elements. However, there are some problematic cases that at first sight seem to contradict our analysis. In this section, we will try to account for these problematic cases, which can be divided into three groups.

The suffixes in the first group, showing mixed behavior, cannot attach to roots and do not influence LB. Consequently, they should be head-suffixes. However, these suffixes seem to be categorially flexible, indicating that they should be rootsuffixes. These suffixes are listed in (15):
a. -ais franç-ais ${ }^{\mathrm{N}+\mathrm{A}}$
'Frenchman'N — 'French'A
b. -ois suéd-ois ${ }^{\mathrm{N}+\mathrm{A}}$
c. -et jeun-et $t^{\mathrm{N}+\mathrm{A}}$
'very young person' ${ }^{\mathrm{N}}$ - 'very young'A
d. -elet gant-elet $^{\mathrm{N}}$ maigr-elet ${ }^{\mathrm{A}}$
'glove' $\mathrm{N}$ 'too thin'A
e. -on fris-on ${ }^{\mathrm{N}+\mathrm{A}}$
'Frisian' ${ }^{\mathrm{N}}-$ 'Frisian'A
f. -ot chemin-ot $t^{\mathrm{N}+\mathrm{A}}$
'railway employee' ${ }^{\mathrm{N}}$ - 'about the railway ${ }^{\mathrm{A}}$

The suffixes in (15) can at first sight derive both nouns and adjectives. However, it will turn out that these suffixes only apparently show flexible behavior. We will first discuss the affixes in (15a and b) and then move to the other examples in (15).

All words derived with the suffixes -ais and -ois (15a,b) in the PRE are indicated as being both adjectives and nouns. Contrary to root-suffixes, there are 
no derivations with -ais or -ois that only have a nominal or adjectival use. Rootsuffixes normally derive words that are only nouns or only adjectives (as exemplified in $(5 a, b))$ and incidentally, forms that are ambiguous between the two. Therefore, the consistent ambiguity of the forms in -ais and -ois requires a separate explanation. We propose that the apparent flexibility of the derivations in $(15 a, b)$ follows from a morphological (or syntactic) operation deriving nouns referring to persons from the toponymic adjectives. This analysis is supported by the fact that all derivations with -ais and -ois have this specific meaning. We consider them to be adjectival derivations that allow for nominalization, as is shown in (16):

(16) a. un homme français ${ }^{\mathrm{A}}$, une ville suédoise ${ }^{\mathrm{A}}$

b. un Français ${ }^{\mathrm{N}}$, le suédois ${ }^{\mathrm{N}}$

We now turn to the suffixes -elet, -et, -on and -ot in (15c-f). These all display the same pattern. The PRE shows that the large majority of derivations with these suffixes are nominal. The list of words with -elet only contains 5 adjectives, which all have been created before 1600. If we oppose this to the truly flexible affixes in (11), we see a marked difference. For example for flexible - $a l$, - el and -iste (17a) we find far more flexibility and productivity than for the 4 affixes under scrutiny (17b).

\begin{tabular}{|c|c|c|c|c|}
\hline & A & $\mathrm{N}$ & $\mathrm{A}$ and $\mathrm{N}$ & most recent form in PRE \\
\hline a. $\quad-$ al & 600 & \pm 130 & 30 & 1951 \\
\hline -el & 233 & \pm 100 & 16 & 1947 \\
\hline -iste & 54 & \pm 430 & 300 & 1921 \\
\hline b. -elet & 5 & 30 & 0 & 1554 (A) \\
\hline -et & 15 & 488 & 10 & 1739 (A) \\
\hline -on & 0 & 3491 & 5 & $1721(\mathrm{~A}$ and $\mathrm{N})$ \\
\hline -ot & 4 & 254 & 8 & $1904(\mathrm{~N}+\mathrm{A})^{5}$ \\
\hline
\end{tabular}

The PRE lists some derivations with -et, -on and -ot that are noun and adjective at the same time, just as for -ais and -ois. Furthermore, the majority of derivations with -on listed as noun and adjective have a special meaning, indicating origin, again like -ais and -ois. We consider these four suffixes to be nominal, deriving nouns of which some easily allow for an adjectival use. The possibility to derive adjectives is not directly related to and therefore not an inherent property of the suffix, but rather a property of the specific type of word.

The second problematic class is formed by the suffix-triplet -able /-ible /-uble. These suffixes attach to roots, but are not categorially flexible, indicating that they could be considered first heads. However, these suffixes precede other first heads,

5. This adjective is marked as 'familier' in the dictionary, meaning that it does not belong to the standard language. 
like -ité, which would not be possible if they were first heads themselves. Secondly, it can be observed that although these suffixes do not undergo LB, because they do not contain the vowels affected by this phenomenon, they do display a formal change when followed by an element that triggers LB, as is shown in (18):

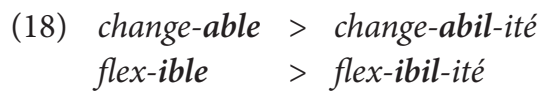

We argue that this formal change is a phonological rule, operating in the rootdomain, just as LB. Therefore, the suffixes -able / -ible / -uble can be analyzed as root-suffixes, because they can attach to roots and display an alternation comparable to LB, even when they are not categorially flexible. However, note that CDF's proposal (just like Lowenstamm's) does not predict that root-suffixes must be categorially flexible. If affixes are roots, they can merge with different categorial heads but they do not have to. Apparently, -able /-ible / -uble only merge with an adjectival head for reasons that might have to do with their semantics.

Finally, there seem to be some counterexamples regarding the ordering of the different suffix-types. According to the theory proposed by CDF, root-suffixes should always appear inside first heads, which in turn should always appear inside head-suffixes. Still, there are some cases where a head-suffix seems to precede a first head or a root-suffix, for which the analysis proposed in this paper does not account. Examples are shown in (19):

$$
\begin{aligned}
& \text {-ag-isme éclairagisme, esclavagisme } \\
& \text {-ment-al gouvernemental, comportemental, départemental }
\end{aligned}
$$

However, although the PRE lists more words ending with -mental next to the three mentioned in (19), it turns out that only the three in (19) are true French derivations, whereas the other words either have been borrowed from Latin or from English. Therefore the number of exceptions to the ordering of the three suffix types seems to be very limited.

\section{Conclusion}

In this paper we have tried to deal with two problematic issues of French derivational suffixes, that is, (i) the fact that the traditional distinction between learned and non-learned suffixes is quite vague and not learnable and (ii) the fact that some suffixes are categorially flexible, deriving words of multiple categories. Using a proposal by Creemers, Don \& Fenger (2015) within the framework of DM, we have proposed a new analysis of French suffixes that shows the presence of three types of suffixes in French too, accounting for the categorial flexibility of some suffixes. 
We argued that it is possible to distinguish three types of suffixes in French. First of all, there are root-suffixes that attach to roots, are categorially flexible, and trigger and are affected by LB. Secondly, there are first heads that attach to roots and influence LB as well, but are not categorially flexible and are not affected by LB. The third type consists of the head-suffixes, which cannot attach to roots, do not influence LB and are not categorially flexible.

Furthermore we have shown that some examples that appear to contradict our theory are actually quite marginal or not problematic after all. Thus we may conclude that the theory makes the correct predictions for French.

\section{References}

Beard, Robert 1995. Lexeme-Morpheme Base Morphology. Albany: SUNY Albany Press.

Creemers, Ava, Jan Don \& Paula Fenger 2015. "Stress-sensitivity and flexibility as a consequence of morphological structure". Proceedings of NELS 45 ed. by Thuy Bui and Deniz Ozyildiz.

De Belder, Marijke 2011. Roots and Affixes: Eliminating lexical categories from syntax. Utrecht: LOT Publications (PhD Dissertation, Utrecht).

Dell, François C. \& Elisabeth O. Selkirk 1978. "On a morphologically governed vowel alternation in French". Recent transformational studies in European languages ed. by Samuel Jay Keyser, 1-51. Cambridge Ma: MIT Press.

Dendien, Jacques. "Trésor de la langue française informatisé (atilf)". <http://atilf.atilf.fr/tlf.htm> (20 March 2015).

Embick, David 2010. Localism versus Globalism in Morphology and Phonology. Cambridge, MA: MIT Press. DOI: 10.7551/mitpress/9780262014229.001.0001

Halle, Morris \& Alec Marantz 1993. "Distributed Morphology and the Pieces of Inflection". The View from Building 20. Essays in Linguistics in honor of Sylvian Bromberger ed. by Morris Hale \& Samuel Jay Keyser, 111-176. Cambridge Ma: MIT Press.

Halle, Morris \& Jean Roger Vergnaud 1987. An Essay on Stress. Cambridge Ma : MIT Press.

Harley, Heidi \& Rolf Noyer 1999. "State-of-the-article: Distributed Morphology". GLOT International 4, 3-9.

Kiparsky, Paul 1982. "From Cyclic Phonology to Lexical Phonology". The Structure of Phonological Representations ed. by Harry van der Hulst and Norval Smith, 131-175. Dordrecht: Foris.

Lowenstamm, Jean 2010. "Derivational Affixes as Roots. (Phasal Spellout meets English Stress Shift)". ms. Université Paris-Diderot \& CNRS.

Marantz, Alec 1997. "No escape from Syntax: Don't try morphological analysis in the privacy of your own lexicon". Proceedings of the 21st Annual Penn Linguistics Colloquium ed. by Alexis Dimitriadis, Laura Siegel, Clarissa Surek-Clark, and Alexander Williams, 201-225. Penn Working Papers in Ling. 4.

Marantz, Alec 2007. "Phases and words". Phases in the theory of grammar ed. by Choe Sook-Hee, 199-222. Seoul: Dong In.

Marvin, Tatjana 2003. Topics in the Stress and Syntax of Words. PhD diss. Cambridge, MA: MIT. Petit Robert 2012. Paris: Dictionnaires le Robert - SEJER.

Petit Robert Electronique, 2015 edition. 
Trommelen, Mieke \& Wim Zonneveld 1989. Klemtoon en Metrische Fonologie. Bussum: Coutinho.

Zwanenburg, Wiecher 1986. "Nom et adjectif en français". Recherches de linguistique française d'Utrecht Vol. 5. ed. by Wiecher Zwanenburg, 35-52. Utrecht: Utrecht University.

\section{Appendix: Lists of suffixes per type}

i. Head-suffixes

$\begin{array}{lll}\text {-ade } & \text {-emment } & \text {-ir } \\ \text {-age } & \text {-ence } & \text {-ise } \\ \text {-aie } & \text {-er } & \text {-ment } \\ \text {-ail(le) } & \text {-erie } & \text {-ois } \\ \text {-ais } & \text {-esque } & \text {-on(ne) } \\ \text {-aison } & \text {-esse } & \text {-onn(er) } \\ \text {-amment } & \text {-et } & \text {-ot } \\ \text {-ance } & \text {-et(er) } & \text {-ot(er) } \\ \text {-ass(er) } & \text {-eton } & \text {-ouill(er) } \\ \text {-eau/-elle } & \text {-eur/-euse } & \text {-oy(er) } \\ \text {-el(er) } & \text {-ie } & -(e) t e ́ \\ \text {-elet } & \text {-illon } & \\ \text {-(e)ment } & \text {-ing } & \end{array}$

ii. First heads

$\begin{array}{lll}\text {-ation } & \text {-is(er) } & \text {-itude } \\ \text {-atique } & \text {-is(se) } & \text {-tion } \\ \text {-ent } & \text {-isme } & \text {-ure } \\ \text {-ifi(er) } & \text {-ité } & \\ \text {-in }(e r) & \text {-iteur/-itrice } & \end{array}$

iii. Root-suffixes

$\begin{array}{lll}\text {-able/-abil } & \text {-éen(ne)/-an } & \text {-if/-ive } \\ \text {-ain/-an } & \text {-el/-al } & \text {-in(e) } \\ \text {-aire/-ar } & \text {-er/-ar } & \text {-iste } \\ \text {-al/-el } & \text {-eur }(f .) & \text {-ite } \\ \text {-at } & \text {-(t)eur/-(t)rice/-or } & \text {-oir(e) } \\ \text {-ataire } & \text {-eur/-or } & \text {-ol(e) } \\ \text {-ateur/-atrice } & \text {-eux/-euse/-os } & \text {-tique } \\ \text {-atif/-ative } & \text {-ible/-ibil } & \text {-uble/-ubil } \\ \text {-atoire } & \text {-ien/-ian } & \end{array}$


Authors' addresses

Jan Don

Department of Dutch

University of Amsterdam

Spuistraat 134

1012 VB Amsterdam

The Netherlands

j.don@uva.nl

Petra Sleeman

Department of Linguistics

University of Amsterdam

Spuistraat 210

1012 VT Amsterdam

The Netherlands

p.sleeman@uva.nl
Thom Westveer

University of Amsterdam

Spuistraat 210

1012 VT Amsterdam

The Netherlands

thom.westveer@student.uva.nl 